\title{
$13: 27542750-27475753$
}

National Cancer Institute

\section{Source}

National Cancer Institute. 13:27542750-27475753. NCI Thesaurus. Code C42283.

Physical location of FLT3_Gene 